University of Nebraska - Lincoln

DigitalCommons@University of Nebraska - Lincoln

\title{
Soil nematode communities are ecologically more mature beneath late- than early-successional stage biological soil crusts
}

\author{
Brian J. Darby \\ University of Vermont, brian.darby@uvm.edu \\ Deborah A. Neher \\ University of Vermont, deborah.neher@uvm.edu \\ Jayne Belnap \\ USGS Southwest Biological Science Center, jayne_belnap@usgs.gov
}

Follow this and additional works at: https://digitalcommons.unl.edu/usgsstaffpub

Darby, Brian J.; Neher, Deborah A.; and Belnap, Jayne, "Soil nematode communities are ecologically more mature beneath late- than early-successional stage biological soil crusts" (2007). USGS Staff -- Published Research. 539.

https://digitalcommons.unl.edu/usgsstaffpub/539

This Article is brought to you for free and open access by the US Geological Survey at DigitalCommons@University of Nebraska - Lincoln. It has been accepted for inclusion in USGS Staff -- Published Research by an authorized administrator of DigitalCommons@University of Nebraska - Lincoln. 


\title{
Soil nematode communities are ecologically more mature beneath late- than early-successional stage biological soil crusts
}

\author{
Brian J. Darby ${ }^{\mathrm{a}, *}$, Deborah A. Neher ${ }^{\mathrm{a}}$, Jayne Belnap ${ }^{\mathrm{b}}$ \\ ${ }^{a}$ Department of Plant and Soil Science, University of Vermont, 105 Carrigan Dr., Burlington, VT 05405, United States \\ ${ }^{\mathrm{b}}$ USGS Southwest Biological Science Center, 2290 S. Resource Blvd., Moab, UT 84532, United States
}

Received 21 November 2005; accepted 12 April 2006

\begin{abstract}
Biological soil crusts are key mediators of carbon and nitrogen inputs for arid land soils and often represent a dominant portion of the soil surface cover in arid lands. Free-living soil nematode communities reflect their environment and have been used as biological indicators of soil condition. In this study, we test the hypothesis that nematode communities are successionally more mature beneath well-developed, late-successional stage crusts than immature, early-successional stage crusts. We identified and enumerated nematodes by genus from beneath early- and late-stage crusts from both the Colorado Plateau, Utah (cool, winter rain desert) and Chihuahuan Desert, New Mexico (hot, summer rain desert) at 0-10 and 10-30 cm depths. As hypothesized, nematode abundance, richness, diversity, and successional maturity were greater beneath well-developed crusts than immature crusts. The mechanism of this aboveground-belowground link between biological soil crusts and nematode community composition is likely the increased food, habitat, nutrient inputs, moisture retention, and/or environmental stability provided by late-successional crusts. Canonical correspondence analysis of nematode genera demonstrated that nematode community composition differed greatly between geographic locations that contrast in temperature, precipitation, and soil texture. We found unique assemblages of genera among combinations of location and crust type that reveal a gap in scientific knowledge regarding empirically derived characterization of dominant nematode genera in deserts soils and their functional role in a crust-associated food web.

(C) 2006 Elsevier B.V. All rights reserved.
\end{abstract}

Keywords: Chihuahuan Desert; Colorado Plateau; Cyanobacteria; Maturity index; Nematodes; Soil food webs; Succession

\section{Introduction}

Aboveground components of terrestrial ecosystems interact with belowground components to affect community and ecosystem processes (Wardle et al., 2004). Primary production, litter accumulation, and rhizophere interactions influence soil biota. In turn, belowground communities affect aboveground components by regulating nutrient flow, litter decomposition,

\footnotetext{
* Corresponding author. Tel.: +1 802656 9482; fax: +18026564656 .

E-mail address: brian.darby@uvm.edu (B.J. Darby).
}

and root herbivory. Many studies have been conducted to examine the influence of soil biota on plant community composition (Wardle et al., 1999; Porazinska et al., 2003; De Deyn et al., 2004a,b) but patterns across time and space are difficult to generalize.

Biological soil crusts often dominate the living cover in arid to semi-arid lands, but can also occur in temperate areas where soil structure or fertility inhibits vascular plant cover, e.g., dry sand savanna (Neher et al., 2003). Biological soil crusts mediate biotic and abiotic conditions supporting life in many extreme environments (Belnap et al., 2003). Crusts increase surface stability (Williams et al., 1995; Belnap and Gillette, 1997, 1998) and soil fertility through dust 
entrapment (Reynolds et al., 2001), photosynthesis (Beymer and Klopatek, 1991), nitrogen fixation (Rychert and Skujins, 1974; West and Skujins, 1977; Rychert et al., 1978; Jeffries et al., 1992) and mineral chelation and retention (Belnap and Harper, 1995; Harper and Belnap, 2001). Biological soil crust establishment begins where bacteria and cyanobacteria colonize the soil surface and secrete extracellular polysaccharides that swell when wet but retain structure when dry. Early-colonizing fungi and cyanobacteria stabilize soil and facilitate the establishment of latercolonizing cyanobacteria (Ashley and Rushforth, 1984; Belnap, 1995). Generally, lichens and mosses colonize later because they require physically stable surfaces (Belnap and Eldridge, 2001). Furthermore, composition of microfloral communities can distinguish biological soil crusts along a gradient from early-successional, cyanobacteria-dominated crusts to late-successional, lichen- and/or moss-dominated crusts (Johansen et al., 1984; Belnap and Eldridge, 2001).

Nematoda are a phylum of soil fauna that play a key role in mediating soil nutrients by feeding on fungi, bacteria, cyanobacteria, green algae, plant roots, and other soil fauna (Bardgett et al., 1999; Whitford, 1996). Nematodes are employed as indicators of the structure and function of the soil community (Neher and Campbell, 1996; Neher et al., 1998) because they represent multiple trophic groups and are ubiquitous, intimately linked to the soil environment, and sensitive to environmental changes (Neher, 2001). One pertinent tool for analysis is the maturity index (MI) to indicate the successional maturity of nematode communities and, thus, the biological condition of the soil habitat (Bongers, 1990). Nematodes are assigned a colonizerpersister value (or $c-p$ value) ranging from enrichment colonizers $(c-p=1)$ and disturbance colonizers $(c-$ $p=2)$ to persisters $(c-p=5)$; the MI is the weighted mean for the frequency distribution of collective $c-p$ values. Colonizers generally exhibit a relatively short lifespan and high fecundity, while persisters are often longer-lived and slower to reproduce (MacArthur and Wilson, 1967; Grime, 1979). Accordingly, soil faunal communities with ample nutrients, but lacking disturbance or eutrophication, are assigned greater MI values than do recently or continually disturbed communities.

The objective of our study was to use the MI and similar community indices, to test the hypothesis that nematode community maturity is correlated positively with the successional maturity of biological soil crusts. The hypothesis is based on the assumption that surface crusts are linked ecologically with soil food webs in arid lands. We predicted that nematode communities beneath well-developed, late-successional crusts would have greater MI values, greater richness and diversity values, and a distinct composition when compared to those beneath the immature, early-successional stage crusts. This comparison was performed at two geographic locations contrasting in climate (temperature and precipitation patterns), and at two soil depths (0-10 and $10-30 \mathrm{~cm})$.

\section{Methods}

\subsection{Sampling}

Soil samples were collected from Canyonlands National Park (southeastern Utah, $38^{\circ} 35.08^{\prime} \mathrm{N}$, $109^{\circ} 49.16^{\prime} \mathrm{W}$ ), and the Jornada experimental range (southern New Mexico, $32^{\circ} 31.80^{\prime} \mathrm{N}, 106^{\circ} 43.41^{\prime} \mathrm{W}$ ) in September 2002. Soils from Canyonlands, Utah, are classified as Rizno series loamy mixed, calcareous soil and soils at Jornada, New Mexico, are a Regan series clay loam. Both soils have $\mathrm{pH}$ of 7.5-8 and low organic matter $(<1 \%)$ in plant interspaces. Summer temperatures are greater at the New Mexico than Utah site, and $65 \%$ of the precipitation in Utah occurs in winter while $65 \%$ of the precipitation in New Mexico occurs during summer (Rosentreter and Belnap, 2001). At each site, we identified five plots (experimental units) for each of two types of biological soil crust cover. At both sites, the filamentous, nonheterocystous cyanobacteria Microcoleus vaginatus dominated the early-successional stage crust type. At the UT site, the late-successional stage crust was a more complex composition of cyanobacteria, lichen (predominantly Collema tenax), and moss (predominantly Syntrichia ruralis). At the NM site, both cyanobacteria and lichen (predominantly Placidium lachneum, $P$. squamulosum, and C. tenax) dominated the late-successional maturity crust. Diversity of cyanobacteria is greater in relatively late- than earlystage crusts, and microbial biomass and diversity associated with late-successional stage crusts is greater at the UT than NM site (Belnap, 2001; Yeager et al., 2004). Each sample (500 g) was representative of a single excavation of soil from $15 \mathrm{~cm}$ diameter and $30 \mathrm{~cm}$ deep. Separate subsamples were collected from each excavation at $0-10$ and 10$30 \mathrm{~cm}$ depth. Samples were kept in an insulated container and transported overnight to Neher lab for processing. All sample weights were corrected for gravimetric soil moisture determined by drying soil to equilibrium at $60{ }^{\circ} \mathrm{C}$. 


\subsection{Nematode enumerations}

Nematodes were extracted from soil using a modified Cobb's decanting and sieving method followed by placing the collected nematodes on a modified Oostenbrink cotton-wool filter extraction tray (s' Jacob and van Bezooijen, 1984) for $48 \mathrm{~h}$. Nematodes were counted, heat-relaxed, fixed in $8 \%$ buffered formalin, and mounted on temporary slides for identification of at least $10 \%$ or up to 150 representative individuals per sample to genus according to Thorne (1974), Jairajpuri and Ahmad (1992), Hunt (1993), Bongers (1994), Siddiqi (2000), and De Ley et al. (2003). Nematodes were assigned to trophic groups according to Yeates et al. (1993a) and colonizer-persister groups based on Bongers (1990).

\subsection{Community indices}

Nematode communities were characterized using six indices. Generic richness was defined as the total number of genera observed per sample. Hill's diversity index was calculated as $N_{1}=\exp \left(-\Sigma p_{i} \ln \left(p_{i}+0.001\right)\right)$ where $p_{i}$ is the proportion of each genus $i$ (Hill, 1973). Maturity index (Bongers, 1990), a measure of nematode community succession, was calculated as $\mathrm{MI}=\Sigma\left(v_{i} p_{i}\right)$, where $v_{i}$, is the colonizer-persister $(c-p)$ value assigned to free-living (not herbivorous) taxa $i$, and $p_{i}$ is the proportion of taxon $i$. The Plant Parasite Index, an ecological maturity index of herbivores, was calculated as PPI $=\Sigma\left(v_{i} p_{i}\right)$ as in the MI but where taxa $i$ include only herbivorous nematodes (Bongers, 1990). Finally, the enrichment index (EI) and structure index (SI) were calculated according to Ferris et al. (2001). Briefly, higher EI values indicate a greater proportion of enrichment microbivores, while greater SI values indicate a larger proportion of omnivores and predators within a community.

\subsection{Statistical analysis}

Three types of statistical procedures were performed to characterize associations among nematode genera and environmental properties. First, analysis of variance (ANOVA) was performed to determine if the proportion of nematode genera differed between location and crust type. This analysis was restricted to observations made in the top $10 \mathrm{~cm}$ of soil because these nematodes were most likely to interact with crust as food and/or habitat. Location, crust type, and the two-way interaction between location and crust were main effects, and proportions of genera were dependent variables.
Secondly, direct gradient canonical correspondence analysis (CCA) was performed to identify patterns of association between nematode community composition and environmental properties. All genera were regarded as species variables and the eight treatment combinations were used as the environmental variables (i.e., 2 locations $\times 2$ crust types $\times 2$ depths $=8$ ). Monte Carlo permutations were employed to test the significance of the first axis and the full model. Thirdly, ANOVA was utilized to test if the community and ecological indices varied with environmental factors. Dependant variables were nematode abundance, generic richness, Hills $N_{1}$ generic diversity, relative abundance of herbivores, fungivores, bacterivores and omnivore/predators, PPI, MI, EI, and SI. Location, crust type, and vertical depth were treated as main effects and all possible two-way interactions were included in the mixed model. Because 0-10 and 10-30 cm samples were dependent, the factor experimental unit (each combination of location and crust) was treated as a random effect variable to compute the component of variance attributable to differences between experimental units prior to calculating the fixed effect of depth. To meet assumptions of Gaussian distribution, abundances of nematodes were $\log$-transformed $[\ln (x+1)]$ and proportions were transformed as the arcsine of square root prior to analysis. MI, PPI, EI, and SI values were not transformed because they already met the assumption of normality. Statistical significance was defined as $\alpha=0.05$ for each variable or eigenvalue tested. Analysis of variance tests were computed with SAS, Statistical Analysis Software, Release 8.00 (SAS Institute Inc., Cary, NC, USA) and CCA were analyzed using CANOCO Version 4.5 software (Wageningen, The Netherlands).

\section{Results}

A cumulative total of 45 genera were observed in the two deserts of which 43 and 27 were found in Utah and New Mexico, respectively. Table 1 lists the genera found in the top $0-10 \mathrm{~cm}$ soil and their relative abundance. Most nematode genera occurred in both shallow and deep soil, but Panagrolaimus and Enchodelus were observed exclusively in $0-10 \mathrm{~cm}$ soils. Furthermore, several genera were established only at $10-30 \mathrm{~cm}$, including Criconemella, Desmolaimus, Discolaimoides, Hemicriconemoides, Longidorus, Nothacrobeles, Nothotylenchus, Rotylenchus, and Xiphinema and, thus, are not illustrated. Location was a significant main effect (ANOVA, $p<0.05$ ) on the relative abundance of 14 genera: Acrobeles, Acromoldavicus, Aphelenchoides, 
Table 1

Nematode genera with assigned feeding group, colonizer-persister classification $(c-p)$, and relative abundance $( \pm$ standard error, $n=5)$ at Utah and New Mexico and beneath early and late-successional stage crusts at $0-10 \mathrm{~cm}$ depth

\begin{tabular}{|c|c|c|c|c|c|c|}
\hline \multirow[t]{2}{*}{ Feeding group } & \multirow[t]{2}{*}{$c-p$ Genus $^{\mathrm{a}}$} & \multicolumn{2}{|l|}{ Utah } & \multicolumn{2}{|l|}{ New Mexico } & \multirow{2}{*}{$\begin{array}{l}\text { ANOVA } \\
\text { summary }\end{array}$} \\
\hline & & Early & Late & Early & Late & \\
\hline Herbivores & $\begin{array}{l}2 \text { Filenchus }^{\mathrm{e}} \\
2 \text { Paratylenchus }^{\mathrm{d}} \\
2 \text { Tylenchus }^{\mathrm{f}} \\
3 \text { Pratylenchus }^{\mathrm{b}} \\
3 \text { Tylenchorhynchus } \\
5 \text { Axonchium } \\
5 \text { Dorylaimellus }\end{array}$ & $\begin{array}{l}12.6 \pm 4.61 \\
0 \\
7.9 \pm 3.68 \\
0.2 \pm 0.00 \\
0 \\
0.1 \pm 0.06 \\
0.4 \pm 0.32\end{array}$ & $\begin{array}{l}9.1 \pm 1.14 \\
0 \\
0.4 \pm 0.21 \\
0 \\
1.6 \pm 0.86 \\
0.8 \pm 0.56 \\
0.2 \pm 0.17\end{array}$ & $\begin{array}{l}0 \\
0 \\
0 \\
0 \\
1.4 \pm 1.42 \\
13.9 \pm 13.92 \\
0\end{array}$ & $\begin{array}{l}0.6 \pm 0.41 \\
1.5 \pm 1.49 \\
0 \\
0.4 \pm 0.43 \\
2.9 \pm 1.93 \\
0.1 \pm 0.11 \\
0.4 \pm 0.43\end{array}$ & $\mathrm{~L}$ \\
\hline Fungivores & $\begin{array}{l}2 \text { Aphelenchus } \\
2 \text { Aphelenchoides } \\
2 \text { Ditylenchus } \\
2 \text { Paraphelenchus } \\
4 \text { Tylencholaimellus } \\
4 \text { Tylencholaimus }\end{array}$ & $\begin{array}{l}1.0 \pm 0.66 \\
9.5 \pm 3.56 \\
1.7 \pm 1.12 \\
0.1 \pm 0.08 \\
0.4 \pm 0.15 \\
0.4 \pm 0.25\end{array}$ & $\begin{array}{r}1.7 \pm 1.70 \\
20.8 \pm 4.81 \\
3.0 \pm 1.23 \\
0 \\
0.1 \pm 0.12 \\
1.0 \pm 0.21\end{array}$ & $\begin{array}{l}14.3 \pm 14.30 \\
2.0 \pm 1.21 \\
1.7 \pm 1.73 \\
0 \\
0 \\
0\end{array}$ & $\begin{array}{l}2.1 \pm 2.10 \\
2.9 \pm 1.25 \\
12.4 \pm 3.94 \\
0 \\
0 \\
0.1 \pm 0.11\end{array}$ & $\begin{array}{l}\mathrm{L} \\
\mathrm{L} \times \mathrm{C}\end{array}$ \\
\hline Bacterivores & $\begin{array}{l}1 \text { Panagrolaimus } \\
2 \text { Acrobeles } \\
2 \text { Acrobeloides } \\
2 \text { Acromoldavicus } \\
2 \text { Cephalobus } \\
2 \text { Cervidellus } \\
2 \text { Chiloplacus } \\
2 \text { Drilocephalobus } \\
2 \text { Heterocephalobus } \\
2 \text { Paracrobeles } \\
2 \text { Plectus } \\
2 \text { Stegelleta } \\
2 \text { Stegelletina }\end{array}$ & $\begin{aligned} 0.1 & \pm 0.06 \\
17.5 & \pm 3.97 \\
0.1 & \pm 0.11 \\
8.1 & \pm 3.23 \\
4.4 & \pm 1.22 \\
14.3 & \pm 1.80 \\
0.2 & \pm 0.16 \\
1.9 & \pm 0.28 \\
0.1 & \pm 0.11 \\
0.4 & \pm 0.26 \\
0.3 & \pm 0.20 \\
0.1 & \pm 0.11 \\
6.0 & \pm 2.30\end{aligned}$ & \begin{aligned} & \multicolumn{1}{l}{0} \\
& 11.2 \pm 1.63 \\
& 0.1 \pm 0.05 \\
& 16.9 \pm 3.19 \\
& 0.5 \pm 0.14 \\
& 18.1 \pm 4.48 \\
& 0.3 \pm 0.28 \\
& 0.6 \pm 0.39 \\
& 0 \\
& 1.9 \pm 1.15 \\
& 0.1 \pm 0.05 \\
& 0 \\
& 5.3 \pm 0.68\end{aligned} & $\begin{array}{l}0 \\
0.4 \pm 0.37 \\
15.3 \pm 5.82 \\
0 \\
1.4 \pm 1.39 \\
25.0 \pm 25.00 \\
0.4 \pm 0.37 \\
0 \\
0 \\
0 \\
0.7 \pm 0.68 \\
0 \\
0\end{array}$ & $\begin{array}{l}0 \\
1.6 \pm 0.90 \\
10.4 \pm 2.60 \\
0 \\
0.2 \pm 0.17 \\
4.5 \pm 3.19 \\
3.3 \pm 2.66 \\
0 \\
0 \\
0 \\
3.3 \pm 2.01 \\
0 \\
3.2 \pm 2.43\end{array}$ & $\begin{array}{l}\mathrm{L} \\
\mathrm{L} \times \mathrm{C} \\
\mathrm{L} \\
\mathrm{L}, \mathrm{L} \times \mathrm{C} \\
\mathrm{L} \\
\mathrm{L}, \mathrm{C}, \mathrm{L} \times \mathrm{C} \\
\mathrm{L}\end{array}$ \\
\hline Predators/omnivores & $\begin{array}{l}4 \text { Discolaimium } \\
4 \text { Enchodelus } \\
4 \text { Eudorylaimus } \\
4 \text { Mylodiscus } \\
4 \text { Thonus } \\
4 \text { Thornia } \\
5 \text { Aporcelaimellus } \\
5 \text { Aporcelaimium } \\
5 \text { Carcharolaimus } \\
5 \text { Nygolaimus }\end{array}$ & $\begin{array}{l}0.1 \pm 0.05 \\
0.1 \pm 0.11 \\
7.2 \pm 1.80 \\
0.1 \pm 0.05 \\
2.3 \pm 0.49 \\
0.1 \pm 0.11 \\
2.7 \pm 1.16 \\
0 \\
0 \\
0.1 \pm 0.06\end{array}$ & $\begin{array}{l}0 \\
0.1 \pm 0.06 \\
2.9 \pm 2.05 \\
0.1 \pm 0.10 \\
1.4 \pm 1.36 \\
0 \\
2.0 \pm 1.47 \\
0 \\
0.2 \pm 0.07 \\
0.1 \pm 0.06\end{array}$ & $\begin{array}{l}0 \\
0 \\
3.5 \pm 2.28 \\
0 \\
4.4 \pm 2.62 \\
0 \\
0 \\
15.6 \pm 10.70 \\
0 \\
0\end{array}$ & $\begin{array}{l}0 \\
0 \\
4.3 \pm 1.47 \\
0 \\
1.7 \pm 1.46 \\
0 \\
0 \\
44.3 \pm 6.65 \\
0 \\
0\end{array}$ & $\begin{array}{l}\mathrm{L} \\
\mathrm{L}, \mathrm{C}, \mathrm{L} \times \mathrm{C} \\
\mathrm{L}, \mathrm{C}, \mathrm{L} \times \mathrm{C}\end{array}$ \\
\hline
\end{tabular}

${ }^{a}$ Herbivore subgroups as in Yeates et al. (1993a); $b=$ migratory endoparasites, $d=$ ectoparasites, e = epidermal cell and root hair feeders, $\mathrm{f}=$ algal, lichen, or moss feeders by piercing; no sedentary parasites were found.

* Significant $(p<0.05)$ effect of: $\mathrm{L}=$ location, $\mathrm{C}=$ crust type, $\mathrm{L} \times \mathrm{C}=$ interaction.

Aporcelaimellus, Aporcelaimium, Carcharolaimus, Cephalobus, Cervidellus, Drilocephalobus, Filenchus, Paracrobeles, Stegelletina, Tylencholaimus, and Tylenchus. Crust type and/or the interaction of location and crust was a significant main effect on the relative abundance of six genera: Acrobeloides, Aporcelaimium, Carcharolaimus, Cephalobus, Ditylenchus, and Drilocephalobus. Four trophic groups were identified in both locations, where herbivores, fungivores, bacterivores and predators/omnivores were represented by 12, 7, 15 and 11 genera, respectively.
Results from canonical correspondence analysis are displayed as a bi-plot ordination diagram (Fig. 1) with each combination of location, crust and depth as an environmental variable vector and points represent relative abundance of each genus. The first CCA axis represents a location gradient between nematodes characteristic of Utah and nematodes characteristic of New Mexico. The second CCA axis suggests that nematode communities are distinguished by depth in New Mexico and by both depth and successional stage of biological soil crust in Utah. Eigenvalues of CCA 


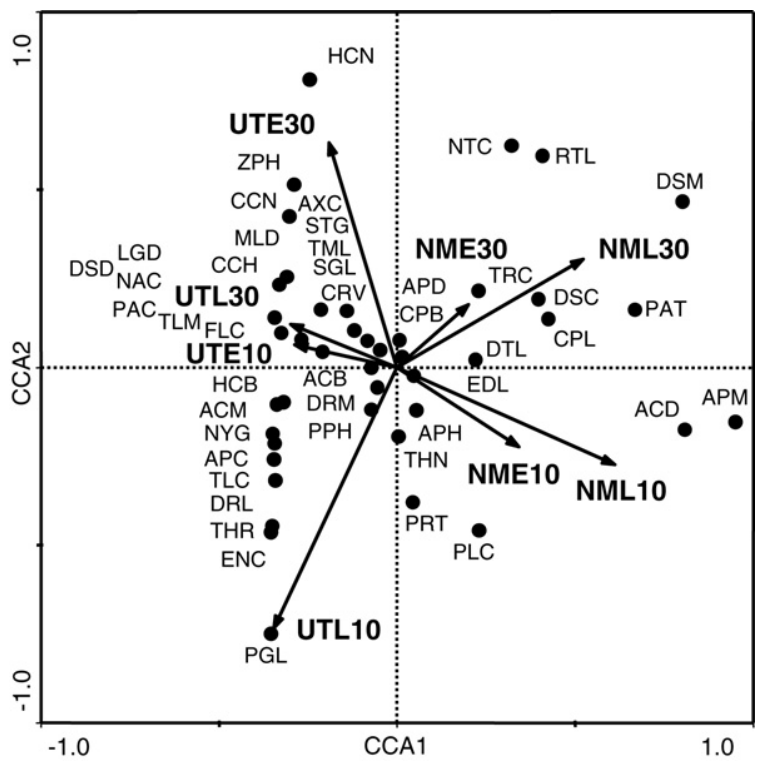

Fig. 1. Canonical correspondence analysis bi-plot of nematode genera modeled with treatment combinations as environmental variables. Points indicate relative abundance of each genus (ACB, Acrobeles; ACD, Acrobeloides; ACM, Acromoldavicus; APC, Aporcelaimellus; APD, Aphelenchoides; APH, Aphelenchus; APM, Aporcelaimium; AXC, Axonchium; $\mathrm{CCH}$, Carcharolaimus; $\mathrm{CCN}$, Criconemella; CPB, Cephalobus; CPL, Chiloplacus; CRV, Cervidellus; DRL, Drilocephalobus; DRM, Dorylaimellus; DSC, Discolaimium; DSD, Discolaimoides; DSM, Desmolaimus; DTL, Ditylenchus; EDL, Eudorylaimus; ENC, Enchodelus; FLC, Filenchus; HCB, Heterocephalobus; HCN, Hemicriconemoides; LGD, Longidorus; MLD, Mylodiscus; NAC, Nothacrobeles; NTC, Nothotylenchus; NYG, Nygolaimus; PAC, Paracrobeles; PAT, Paratylenchus; PGL, Panagralaimus; PLC, Plectus; PPH, Paraphelenchus; PRT, Pratylenchus; RTL, Rotylenchus; SGL, Stegelletina; STG, Stegelleta; THN, Thonus; THR, Thornia; TLC, Tylenchus; TLM, Tylencholaimus; TML, Tylencholaimellus; TRC, Tylenchorhyncus; ZPH, Xiphinema) and vectors of treatment combinations are coded for location (UT = Utah, $\mathrm{NM}=$ New Mexico), crust type $(\mathrm{E}=$ early-successional stage, $\mathrm{L}=$ late-successional stage $)$, and depth $(10=0-10 \mathrm{~cm}, 30=10$ $30 \mathrm{~cm}$ ).

axis $1(0.293, p=0.0020)$ and axis $2(0.092)$ explained $63.3 \%$ of the total species-environment variance. The species-environment correlations were large for both axis $1(0.962)$ and $2(0.845)$.

Total nematode abundance, generic richness, Hills $N_{1}$ generic diversity, proportion of herbivores, and proportion of bacterivores were greater in Utah than New Mexico (Table 2). In contrast, values of MI and PPI were greater in New Mexico than Utah. Similarly, total abundance, generic richness, Hills $N_{1}$ generic diversity, proportion of herbivores, proportion of omnivores/ predators, MI values and SI values were greater in latethan early-stage crusts (Table 2). The opposite pattern was observed for proportion of fungivores and PPI

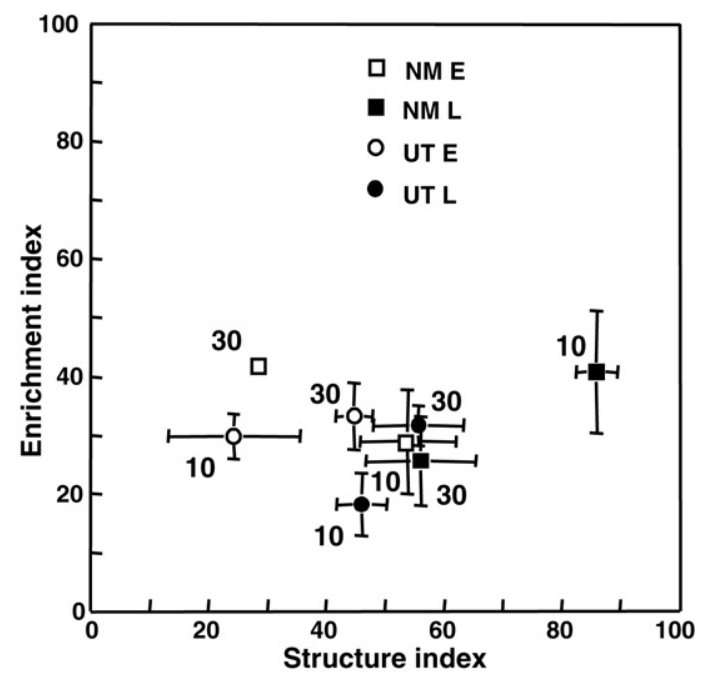

Fig. 2. Structure-enrichment plot for each treatment combination ( \pm standard error, $n=5$ ). Points indicate location $($ circles $=U$ Utah, squares $=$ New Mexico) and crust type (solid = late-successional stage crust, open = early-successional stage crust $)$ and adjacent numerals indicate depth $(10=0-10 \mathrm{~cm}, 30=10-30 \mathrm{~cm})$.

values. Metrics of community assemblage were not as consistent with soil depth because the effect of depth typically interacted significantly with geographic location and/or crust stage (Table 2). For example, MI and SI values were greater in shallow $(0-10 \mathrm{~cm})$ than deep $(10-30 \mathrm{~cm})$ soils in New Mexico but the opposite in Utah (Fig. 2). Likewise, generic richness and Hills $N_{1}$ generic diversity values were greater in deep than shallow soils in all treatment combinations except early-stage crusts in New Mexico. There was no significant effect of crust stage or soil depth on relative abundance of fungivores or EI values (Table 2).

\section{Discussion}

As hypothesized, nematode communities were consistently more diverse and ecologically mature beneath relatively late- than early-successional stage crusts; we observed a positive association between surface and belowground community patterns. In both geographic locations of the present study, relative dominance of dorylaim predator/omnivore genera was positively associated with large values of successional maturity of nematode communities in late-stage crusts. Likewise, Wall et al. (2002) and Wasilewska (2002) observed a similar shift in nematode composition that paralleled the succession of the aboveground vegetation in a sand dune and peat meadow, respectively. They noted that later stages in ecological succession corresponded with increased numbers of omnivore/ 
Table 2

Mean values ( \pm standard error, $n=5$ ) of nematode community indices taken from Utah and New Mexico beneath early and late-successional stage crusts at $0-10 \mathrm{~cm}$ and $10-30 \mathrm{~cm}$ depth

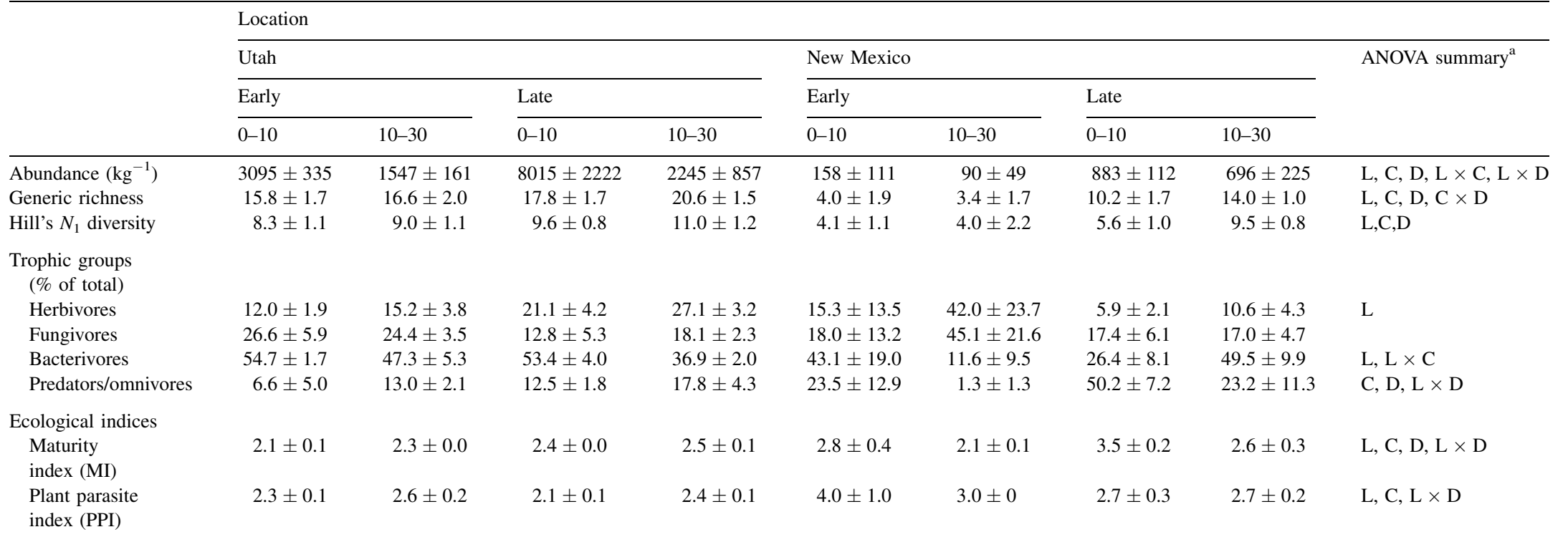

${ }^{a}$ Letters indicate significant (ANOVA, $p<0.05$ ) effects: $\mathrm{L}=$ location, $\mathrm{C}=$ crust, $\mathrm{D}=$ depth, or two-way interaction effects $(\mathrm{L} \times \mathrm{C}, \mathrm{L} \times \mathrm{D}$, and $\mathrm{C} \times \mathrm{D}$ ). Experimental units unique to each location $\times$ crust combination were treated as the random effect in the mixed model. 
predators (but see Goralczyk, 1998). Steinberger et al. (1984) observed a similar relationship in the Chihuahuan Desert where omnivorous nematodes were more abundant with greater quantities of dry surface litter. This is not the first study to show that successional stage of the fauna can parallel that of the dominant flora. For example, community attributes of soil arthropods were affected by the development of tropical inselbergs (Kounda-Kiki et al., 2004) and ant communities developed in parallel to rehabilitating ash dams (Van Hamburg et al., 2004).

The biological soil crust likely affects nematodes in several ways. First, the increased nitrogen fixation, primary production, and chelation of metals of cyanobacteria, lichens, and mosses in a well-developed, late stage crust increases the amount and availability of nutrient sources that can support secondary and tertiary consumers (reviewed in Belnap et al., 2003). Second, the greater biomass and diversity of late-stage crust organisms directly provide more abundant and more diverse food for nematodes. Third, soil moisture retention can be greater in well-developed crusts (George et al., 2003), which may increase the period of time in which nematodes can be active and feeding. Finally, the crust forms a boundary between the atmosphere and mineral soil (Belnap et al., 2003) that increases the stability of the soil environment and may allow the persistence of more nematodes that are sensitive to disturbance.

In contrast to other studies of nematodes in soils of arid lands, abundance of nematodes in Utah (this study) was relatively large (Fig. 3). Values in this study were similar to those found in soils receiving organic amendments, receiving rainfall, or occurring near vascular plants. Despite the large abundance of nematodes and general dominance of bacterivores, the nematode communities associated with late-stage crusts appear most characteristic of moderate-mesotrophic habitat than enriched-eutrophic habitat for microfauna because of relatively high richness and diversity values and negligible abundance of enrichment microbivores. This is compatible with unimodel productivity-diversity gradients (Grime, 1979; Rosenzweig, 1992; and Kassen et al., 2000; but see Waide et al., 1999).

Nematode community composition contrasted mostly by geographic locations, which represented contrasting patterns of temperature, precipitation, and soil texture. Furthermore, community composition was distinguished by depth more in New Mexico than Utah soils. The results of our study support the hypothesis of Whitford (1989) who proposed that in moist, thermally neutral environments, all components of the generalized

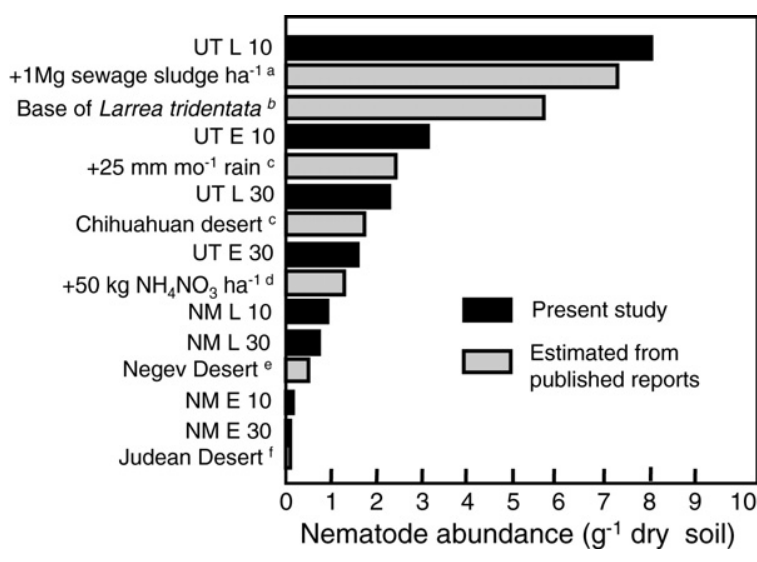

Fig. 3. Comparison of mean nematode abundance from various arid land nematode studies. Values are labeled by treatment description and include present study (dark bars) or estimates from published reports (light bars). For present study, UT $=\mathrm{Utah}, \mathrm{NM}=\mathrm{New}$ Mexico, $\mathrm{E}=$ early-successional stage crusts, $\mathrm{L}=$ late-successional stage crusts, $10=0-10 \mathrm{~cm}$ soil, and $30=10-30 \mathrm{~cm}$ soil. Values from published reports are generally taken from shallow soil, away from plants, without artificial amendments, and during late summer season, unless noted otherwise by treatment description. Literature sources include ${ }^{\mathrm{a}}$ Whitford et al. (1989), ${ }^{\mathrm{b}}$ Freckman and Mankau (1986), ${ }^{\mathrm{c}}$ Freckman et al. (1987), ${ }^{\mathrm{d}}$ Alon and Steinberger (1999), ${ }^{\mathrm{e}}$ Liang et al. (2002), and ${ }^{\mathrm{f}}$ Steinberger et al. (2001).

food web are active and the trophic relationships are as complex as the taxonomic diversity of the soil biota. In contrast, the trophic relationships of dry and thermally extreme environments are only a subset of the full ensemble, confined (or restricted) to taxa capable of tolerating extreme abiotic conditions. Whitford further hypothesized that abiotic controls will be more important in hot and cold deserts and will vary in importance in other ecosystems. In our study, abiotic factors related to soil depth appear to influence nematode community composition in New Mexico (hotter desert with more summer rain) more so than the biotic factors associated with crust succession. In this case, we assume that abiotic properties, such as rate of dehydration, temperature fluctuation, and radiation, are greater at $0-10$ than $10-30 \mathrm{~cm}$ depth. In contrast, nematode community composition was similar at both depths in the less stressful climatic conditions of Utah (cool-desert with winter precipitation).

We are unable to explain the greater MI values for New Mexico than Utah. One conspicuous genus in New Mexico was Aporcelaimium, an omnivore/predator of $c-p=5$, which comprised a mean $44.3 \%$ of the entire nematode community beneath late-stage crusts in New Mexico. Biologically, it is unclear how to interpret the presence of this single genus in large abundance, but it was responsible for inflating MI values for New Mexico 
beyond what we would expect for a thermally stressed environment. We know that closely related species in the same family (Aporcelaimidae) have a diverse omnivorous diet (Small, 1987) and can be reared on algae (Wood, 1973). Many individuals from this study were likely feeding on cyanobacteria or green algae as indicated by their distinctly green gut contents (personal observation). In addition to Aporcelaimidae, we cannot explain the contrasts in dominant taxa within trophic groups. For example, Axonchium and Tylenchorhynchus were dominant herbivores in New Mexico, but Filenchus and Tylenchus were dominant in Utah. Aphelenchus and Ditylenchus were dominant fungivores in New Mexico while Aphelenchoides was a dominant fungivore in Utah. Cervidellus was a common bacterivore at both locations, but Acrobeloides was greater in relative abundance in New Mexico while Acrobeles and Acromoldavicus were more abundant in Utah. These patterns invoke questions concerning the pattern of community assemblage in these systems (Weiher and Keddy, 2001). We hypothesize these nematodes differ in tolerance of heat and dessication. Therefore, contrasting shifts in temperature and precipitation patterns among deserts, as a result of climate change, will be a primary determinant of community composition and secondarily by food preferences and biotic interactions.

Studies of free-living nematode communities are frequently limited by an incomplete knowledge of trophic habits. Feeding groups are assigned usually based on morphology or taxonomic relation to previous observations rather than empirically. Although this study helps to create hypotheses concerning individual feeding habits, there is still much to learn. Likely, trophic linkages between crust components and nematodes are a mixture of direct or indirect feeding of nematodes on microbial decomposers or crust components. For example, De Ley (1992) hypothesized that Cephalobidae (the dominant bacterivorous family in arid lands) might actually be substrate ingestors. Biological soil crust organisms secrete carbon-rich extracellular polysaccharides during wetting and drying cycles (Belnap, 2001). Late-successional stage crusts have greater biomass and, therefore, greater secretions, so it is likely that many nematodes could utilize this as a significant food source. Few of the potentially herbivorous taxa (i.e., styletbearing) of this study are known to be strict plantparasitic-type herbivores. For example, Tylenchidae (represented by Tylenchus and Filenchus in this study) is often categorized an herbivores, but it has been shown that fungivory may be more common for some species of this family (Okada et al., 2002,2005; Okada and Kadota,
2003). Microbial grazers often influence the growth and physiology of their food source. Therefore, if a strong trophic link exists between crust flora and certain nematode taxa, there is a possibility that grazing may regulate feedback dynamics with crust components. Examples include (a) protozoan grazing stimulates nitrogen fixation in Azotobacter chrococcum cultures in liquid (Nasir, 1923) and soil (Cutler and Bal, 1926) media, (b) mixed desert soil fauna increase nitrogen accumulation under certain environmental conditions (Ghabbour et al., 1980), and (c) nitrogen fixation rates are greatest at intermediate levels of collembolan grazer populations in Antarctic cyanobacterial crusts (Birkemoe and Liengen, 2000). More encompassingly, Bever et al. (1997) demonstrated how soil communities could affect aboveground plant populations through feedback dynamics. Understanding these dynamics will help us to determine if the relationship between biological soil crusts soil nematodes is unidirectional or more complex.

In conclusion, we characterized the microfaunal communities in an arid soil beneath the biological crust formations of two southwestern U.S. deserts and made the key observation that nematode communities were distinct between contrasting successional stages of crust development. Nematodes were more abundant, diverse, and successionally mature when associated with welldeveloped, late-successional than immature, earlysuccessional crusts. Biological soil crusts directly influence nutrient cycling and other ecosystem functions, so our results suggest that the composition of nematode fauna associated with soil crusts may indirectly influence these processes. We will need a more complete understanding of feeding habits and tolerances for each dominant nematode genus to abiotic stress before soil nematode community indices can be interpreted and calibrated accurately as biological indicators of arid land soil condition and function.

\section{Acknowledgements}

We thank David Housman and Thomas R. Weicht for their assistance in collecting and processing samples. This research was funded by Department of Energy, Program for Ecosystem Research award DE-AI0202ER63381.

\section{References}

Alon, A., Steinberger, Y., 1999. Effect of nitrogen amendments on microbial biomass, aboveground biomass and nematode population in the Negev Desert soil. J. Arid Environ. 41, 429-441. 
Ashley, J., Rushforth, S.R., 1984. Growth of soil algae on top soil and processed oil shale from the Utah Basin, Utah, USA. Reclam. Reveg. Res. 3, 49-63.

Bardgett, R.D., Cook, R., Yeates, G.W., Denton, C.S., 1999. The influence of nematodes on below-ground processes in grassland ecosystems. Plant Soil 212, 23-33.

Belnap, J., 1995. Surface disturbances: their role in accelerating desertification. Environ. Monit. Assess. 37, 39-57.

Belnap, J., 2001. Comparative structure of physical and biological soil crusts. In: Belnap, J., Lange, O.L. (Eds.), Biological Soil Crusts: Structure, Function, and Management. Ecological Studies Series 150. Springer-Verlag, Berlin, pp. 177-191.

Belnap, J., Eldridge, D., 2001. Disturbance and recovery of biological soil crusts. In: Belnap, J., Lange, O.L. (Eds.), Biological Soil Crusts: Structure, Function, and Management. Ecological Studies Series 150. Springer-Verlag, Berlin, pp. 363-383.

Belnap, J., Gillette, D.A., 1997. Disturbance of biological soil crusts: impacts on potential wind erodibility of sandy desert soils in southeastern Utah. Land Degrad. Dev. 8, 355-362.

Belnap, J., Gillette, D.A., 1998. Vulnerability of desert biological soil crusts to wind erosion: the influences of crust development, soil texture, and disturbance. J. Arid Environ. 39, 133142.

Belnap, J., Harper, K.T., 1995. Influence of cryptobiotic soil crusts on elemental content of tissue of 2 desert seed plants. Arid Soil Res. Rehab. 9, 107-115.

Belnap, J., Hawkes, C.V., Firestone, M.K., 2003. Boundaries in miniature: two examples from soil. Bioscience 53, 739-749.

Bever, J.D., Westover, K.M., Antonovics, J., 1997. Incorporating the soil community into plant population dynamics: the utility of the feedback approach. J. Ecol. 85, 561-573.

Beymer, R.J., Klopatek, J.M., 1991. Potential contribution of carbon by microphytic crusts in pinyon-juniper woodlands. Arid Soil Res. Rehab. 5, 187-198.

Birkemoe, T., Liengen, T., 2000. Does collembolan grazing influence nitrogen fixation by cyanobacteria in the high arctic? Polar Biol. 23, 589-592.

Bongers, T., 1994. De Nematoden van Nederland. Koninklejke Nedelandse Natuuhistorische Vereniging. Utrecht, The Netherlands.

Bongers, T., 1990. The maturity index: an ecological measure of environmental disturbance based on nematode species composition. Oecologia 83, 14-19.

Cutler, D.W., Bal, D.V., 1926. Influence of protozoa on the process of nitrogen fixation by Azotobacter chrococcum. Ann. Appl. Biol. 13, 516-534.

De Deyn, G.B., Raaijmakers, C.E., Van Der Putten, W.H., 2004a. Plant community development is affected by nutrients and soil biota. J. Ecol. 92, 824-834.

De Deyn, G.B., Raaijmakers, C.E., Van Ruijven, J., Berendse, F., Van Der Putten, W.H., 2004b. Plant species identity and diversity effects on different trophic levels of nematodes in the soil food web. Oikos 106, 576-586.

De Ley, P., 1992. The nematode community of a marginal soil at Cambérène, Senegal, with special attention to functional morphology and niche partitioning in the family Cephalobidae. Mededelingen van de Koninklijke Academic voor Wetenschappen, Letteren en Schone Kunsten van België-Klasse der Wetenschappen 53, 108-153.

De Ley, P., De Ley, I.T., Mundo-Ocampo, M., Mundo, L., Baldwin, J.G., 2003. Identification of Freeliving Nematodes-Secernentea. University of California Extension, Riverside, California.
Ferris, H., Bongers, T., De Goede, R.G.M., 2001. A framework for soil food web diagnostics: extension of the nematode faunal analysis concept. Appl. Soil Ecol. 18, 13-29.

Freckman, D.W., Mankau, R., 1986. Abundance, distribution, biomass and energetics of soil nematodes in a Northern Mojave Desert ecosystem. Pedobiologia 29, 129-142.

Freckman, D.W., Whitford, W.G., Steinberger, Y., 1987. Effect of irrigation on nematode population-dynamics and activity in desert soils. Biol. Fert. Soils 3, 3-10.

George, D.B., Roundy, B.A., St. Clair, L.L., Johansen, J.R., Schaalje, G.B., Webb, B.L., 2003. The effects of microbiotic soil crusts on soil water loss. Arid Land Res. Manag. 17, 113-125.

Ghabbour, S.I., El-Ayouty, E.Y., Khadr, M.S., El Tonsi, A.-M.S., 1980. Grazing by microfauna and productivity of heterocystous nitrogen-fixing blue-green algae in desert soils. Oikos 34, 209-218.

Goralczyk, K., 1998. Nematodes in a coastal dune succession: indicators of soil properties? Appl. Soil Ecol. 9, 465-469.

Grime, J.P., 1979. Plant Strategies and Vegetation Processes. John Wiley and Sons Ltd., New York, NY.

Harper, K.T., Belnap, J., 2001. The influence of biological soil crusts on mineral uptake by associated vascular plants. J. Arid Environ. 47, 347-357.

Hill, M.O., 1973. Diversity and evenness: a unifying notation and its consequences. Ecology 54, 427-432.

Hunt, D.J., 1993. Aphelenchida, Longidoridae and Trichodoridae: Their Systematics and Bionomics. CAB International, Cambridge, UK.

Jairajpuri, M.S., Ahmad, W., 1992. Dorylaimida: Free-Living, Predaceous and Plant-Parasitic Nematodes. E.J. Brill, New York.

Jeffries, D.L., Klopatek, J.M., Link, S.O., Bolton, H., 1992. Acetylene-reduction by cryptogamic crusts from a blackbrash community as related to resaturation and dehydration. Soil Biol. Biochem. 24, 1101-1105.

Johansen, J.R., St. Clair, L.L., Webb, B.L., Nebeker, G.T., 1984. Recovery patterns of cryptogamic soil crusts in desert rangelands following fire disturbance. Bryologist 87, 238-243.

Kassen, R., Buckling, A., Bell, G., Rainey, P.B., 2000. Diversity peaks at intermediate productivity in a laboratory microcosm. Nature 406, 508-512.

Kounda-Kiki, C., Vaculik, A., Ponge, J.F., Sarthou, C., 2004. Soil arthropods in a developmental succession on the Nouragues Inselberg (French Guiana). Biol. Fert. Soils 40, 119-127.

Liang, W.J., Mouratov, S., Pinhasi-Adiv, Y., Avigad, P., Steinberger, Y., 2002. Seasonal variation in the nematode communities associated with two halophytes in a desert ecosystem. Pedobiologia 46, 63-74.

MacArthur, R.H., Wilson, E.O., 1967. The Theory of Island Biogeography. Princeton University Press, Princeton, New Jersey.

Nasir, S.M., 1923. Some preliminary investigations on the relationship of protozoa to soil fertility with special reference to nitrogen fixation. Ann. Appl. Biol. 10, 122-133.

Neher, D.A., 2001. Role of nematodes in soil health and their use as indicators. J. Nematol. 33, 161-168.

Neher, D.A., Campbell, C.L., 1996. Sampling for regional monitoring of nematode communities in agricultural soils. J. Nematol. 28, 196-208.

Neher, D.A., Easterling, K., Fiscus, D., Campbell, C.L., 1998. Comparison of nematode communities in agricultural soils of North Carolina and Nebraska. Ecol. Appl. 8, 213-223.

Neher, D.A., Walters, T.L., Tramer, E., Weicht, T.R., Veluci, R.M., Saiya-Cork, K., Will-Wolf, S., Toppin, J., Traub, J., Johansen, J.R., 2003. Biological soil crust and vascular plant communities in a 
sand savanna of northwestern Ohio. J. Torrey Bot. Soc. 130, 244-252.

Okada, H., Harada, H., Kadota, I., 2005. Fungal-feeding habits of six nematode isolates in the genus Filenchus. Soil Biol. Biochem. 37, $1113-1120$.

Okada, H., Kadota, I., 2003. Host status of 10 fungal isolates for two nematode species, Filenchus misellus and Aphelenchus avenae. Soil Biol. Biochem. 35, 1601-1607.

Okada, H., Tsukiboshi, T., Kadota, I., 2002. Mycetophagy in Filenchus misellus (Andrassy, 1958) Lownsbery \& Lownsbery, 1985 (Nematoda: Tylenchidae), with notes on its morphology. Nematology 4, 795-801.

Porazinska, D.L., Bardgett, R.D., Blaauw, M.B., Hunt, H.W., Parsons, A.N., Seastedt, T.R., Wall, D.H., 2003. Relationships at the aboveground-belowground interface: plants, soil biota, and soil processes. Ecol. Monogr. 73, 377-395.

Reynolds, R.L., Belnap, J., Reheis, M., Lamothe, P., Luiszer, F., 2001. Aeolian dust in Colorado Plateau soils: nutrient inputs and recent change in source. Proc. Natl. Acad. Sci. U.S.A. 98, 7123-7127.

Rosentreter, R., Belnap, J., 2001. Biological soil crusts of North America. In: Belnap, J., Lange, O.L. (Eds.), Biological Soil Crusts: Structure, Function, and Management. Springer-Verlag, Berlin, pp. 31-55.

Rosenzweig, M.L., 1992. Species-diversity gradients-we know more and less than we thought. J. Mammol. 73, 715-730.

Rychert, R.C., Skujins, J., 1974. Nitrogen fixation by blue-green algae-lichen crusts in the Great Basin Desert. Soil Sci. Soc. Am. Proc. 38, 768-771.

Rychert, R.C., Skujins, J., Sorensen, D., Porcella, D., 1978. Nitrogen fixation by lichens and free-living microorganisms in deserts. In: West, N.E., Skujins, J. (Eds.), Nitrogen in Desert Ecosystems. Dowden, Hutchinson and Ross, Inc., Stroudsburg, pp. 20-30.

s'Jacob, J.J., van Bezooijen, J., 1984. A Manual for Practical Work in Nematology. Wageningen Agricultural University, Wageningen, The Netherlands.

Siddiqi, M.R., 2000. Tylenchida: Parasites of Plants and Insects, 2nd ed. CAB International, Cambridge, UK.

Small, R.W., 1987. A review of the prey of predatory soil nematodes. Pedobiologia 30, 179-206.

Steinberger, Y., Freckman, D.W., Parker, L.W., Whitford, W.G., 1984. Effects of simulated rainfall and litter quantities on desert soil biota-nematodes and microarthropods. Pedobiologia 26, 261-274.

Steinberger, Y., Liang, W.J., Savkina, E., Meshi, T., Barness, G., 2001. Nematode community composition and diversity associated with a topoclimatic transect in a rain shadow desert. Eur. J. Soil Biol. 37, 315-320.

Thorne, G., 1974. Nematodes of the Northern Great Plains. Part II. Dorylaimoidea in part (Nemata: Adenophorea), Tech. Bull. 41.
Agricultural Experiment Station, South Dakota State University, Brookings, SD.

Van Hamburg, H., Andersen, A.N., Meyer, W.J., Robertson, H.G., 2004. Ant community development on rehabilitated ash dams in the South African Highveld. Restor. Ecol. 12, 552-558.

Waide, R.B., Willig, M.R., Steiner, C.F., Mittelbach, G., Gough, L., Dodson, S.I., Juday, G.P., Parmenter, R., 1999. The relationship between productivity and species richness. Annu. Rev. Ecol. Syst. 30, 257-300.

Wall, J.W., Skene, K.R., Neilson, R., 2002. Nematode community and trophic structure along a sand dune succession. Biol. Fert. Soils 35, 293-301.

Wardle, D.A., Bardgett, R.D., Klironomos, J.N., Setala, H., Van Der Putten, W.H., Wall, D.H., 2004. Ecological linkages between aboveground and belowground biota. Science 304, 1629-1633.

Wardle, D.A., Bonner, K.I., Barker, G.M., Yeates, G.W., Nicholson, K.S., Bardgett, R.D., Watson, R.N., Ghani, A., 1999. Plant removals in perennial grassland: vegetation dynamics, decomposers, soil biodiversity, and ecosystem properties. Ecol. Monogr. 69, 535-568.

Wasilewska, L., 2002. Post-drainage secondary succession of soil nematodes on fen peat meadows in Biebrza wetlands, Poland. Pol. J. Ecol. 50, 269-300.

Weiher, E., Keddy, P., 2001. Ecological Assembly Rules. Cambridge University Press, Cambridge.

West, N.E., Skujins, J., 1977. The nitrogen cycle in North American cold-winter semi-desert ecosystems. Ecol. Plant. 12, 45-53.

Whitford, W.G., 1989. Abiotic controls on the functional structure of soil food webs. Biol. Fert. Soils 8, 1-6.

Whitford, W.G., 1996. The importance of the biodiversity of soil biota in arid ecosystems. Biodiv. Conserv. 5, 185-195.

Whitford, W.G., Aldon, E.F., Freckman, D.W., Steinberger, Y., Parker, L.W., 1989. Effects of organic amendments on soil biota on a degraded rangeland. J. Range Manage. 42, 56-60.

Williams, J.D., Dobrowolski, J.P., West, N.E., Gillette, D.A., 1995 Microphytic crust influence on wind erosion. Trans. ASAE 38 131-137.

Wood, F.H., 1973. Biology of Aporcelaimellus sp. (Nematoda: Aporcelaimidae). Nematologica 19, 528-537.

Yeager, C.M., Kornosky, J.L., Housman, D.C., Grote, E.E., Belnap, J., Kuske, C.R., 2004. Diazotrophic community structure and function in two successional stages of biological soil crusts from the Colorado Plateau and Chihuahuan Desert. Appl. Environ. Microb. 70, 973-983.

Yeates, G.W., Bongers, T., de Goede, R.G.M., Freckman, D.W., Georgieva, S.S., 1993a. Feeding habits in soil nematode families and genera-an outline for soil ecologists. J. Nematol. 25 , $315-331$. 